
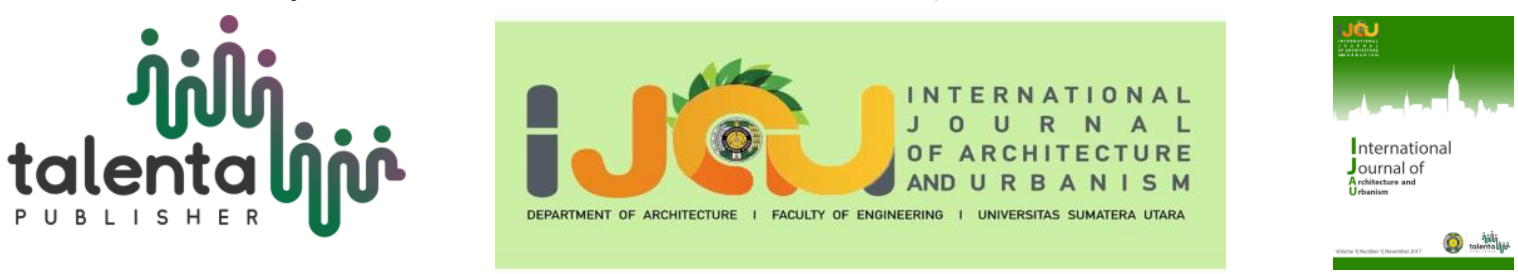

\title{
Towards Walkability: Qualitative Assessment of Pedestrian Environment in Yogyakarta and Singapore
}

\author{
Odilia Renaningtyas Manifesty ${ }^{1^{*}}$
}

${ }^{1}$ PhD Student, Department of Architecture, College of Engineering, Korea University, Seoul, South Korea

\begin{abstract}
After the publication of Urban Sprawl and Public Health, the argument of providing nice pedestrian facilities is not only concerned about aesthetic and social aspects, but also about the health improvement of the people. The shift has made the world's major cities realize the importance of good pedestrian design. Walkable City has become the current goal in city development for most countries in South-east Asia, including Indonesia and Singapore. Indonesian cities such as Surabaya and Jakarta have made attempts on promoting walking habits through several programs such as children friendly public space development and riverfront revitalization. Yogyakarta, also Indonesia's major city, still struggles in encouraging its citizens to walk more. This study observed the current condition of the city's pedestrian system and facilities. The result showed that the main cause of the discouragement is the street condition that doesn't put the pedestrian as the prime user. Improvements have been made at several sections of the street, showing the government's real effort on fixing the problem. Comparative study with Singapore's pedestrian facilities was conducted and it showed that to encourage people to walk, it is not just about providing good street infrastructure, but more to enhancing people's walking experience.
\end{abstract}

Keyword: liveability, urban, street, pedestrian, comparative

Received 20 March 2021 | Revised 22 August 2021 | Accepted 26 August 2021

\section{Introduction}

The extremely fast industrialization and trading change has made the 20th century to be one of the most progressive eras of human civilization. One of the clear examples is the birth and advancement of automobiles in the early to mid-20th century. Later in this era, car ownership has become a tool for people to elevate their social status. A major shift was happening in the 21 st century when cars, especially in cities, are considered too much. Researchers for interdisciplinary subjects had learned the negative effect of cars in the environment. As an effect, since 1960 car industries have tried to develop methods to make more environmentallyfriendly vehicular technology[1]. The effort has gradually gained success in producing cars with

*Corresponding author at: Urban Planning and Design Lab, Department of Architecture, Faculty of Engineering, Korea University, Seoul, South Korea.

E-mail address: ormreyn@korea.ac.kr

Copyright (c) 2021 Published by Talenta Publisher, 
less dangerous residue, but the excessive advertisement of such achievement only made people to own more cars and leave less space on the street for people to walk. As major cities in Southeast Asia, Singapore and Yogyakarta are progressing towards a greener development through pedestrian encouragement. Following the commitment of the cities a research question was constructed: how is the current condition of the pedestrian environment of both cities? To answer the question, this paper presented an early assessment on Yogyakarta's current pedestrian system and a precedent of Singapore's pedestrian system is also presented to give a depiction of a more advanced pedestrian environment.

\section{Literature Review}

\subsection{Positioning Pedestrian Street Design in Indonesian Cities}

The fact that people are leaving walking habits behind and becoming extremely dependable to automobiles is such an irony since at the beginning of time until before the mid 19th century, walking was the primary transportation for the people. Pedestrian streets that used to be full of plazas, greeneries, and retails were turned into automobile alleys in the industrial era. Streets were starting to focus on providing parking for private automobiles rather than space for people to walk [2]. In the United States, street grids are losing their connectivity and lessening the walkability value in less than a century [3]. Solutions to this problem had surfaced from many field studies, including Architecture and Urban Design. Movements and trends in urban design are made to overcome such problems, for example is City Beautiful and Garden City that consider pedestrian streets as a must have aesthetic and leisure point. Moving to the $21 \mathrm{st}$ century, promoting walking habits is considered as one foundation of a sustainable city. The benefits of walking habits have an impact not only to the reduction of the negative effects of automobiles but also to the improvement of public health [4]. Streets as urban social space can also help people to reduce stress and it is proven in many European cities such as Rome, Barcelona, and Paris that beautiful pedestrian-oriented streets are able to attract tourists and bring income to communities.

All things mentioned above have led to a new paradigm in urban design concerning the importance of a good pedestrian environment to promote walking habits. This is to be achieved in this modern world in order to attain greener city development and healthier lifestyle. First effort to achieve the goal is to provide a medium for people to walk. Stated on the famous book of 'Walkable City' by Jeff Speck (2012), the modern design of pedestrian streets should comply with four criteria: it must provide safety, meaning, comfort, and has to spark interest. Megacities in developed countries have started to design their streets to fulfill the criteria. However, in developed countries such as Indonesia, the concern of the pedestrian environment is still too centered on the technicality of the safety aspect. As an initial attempt on creating a pedestrian 
system, Indonesia's Directorate of Spatial Planning has made several categories regarding pedestrian street typologies along with its regulation. The types are sidewalk, promenade, arcade, green pathway, underground street, and elevated street [5]. However pedestrian streets in Yogyakarta only show only the sidewalk and green pathway types and most of them are still not meeting the standard.

\subsection{Learning from Singapore's Advance Pedestrian System}

As the most developed country in Southeast Asia, Singapore has been building a comfortable pedestrian environment as the nation's urban agenda. Most streets can generate secondary activity besides walking, and it was planned in consideration of pedestrian streets as part of a multimodal transportation hub [6]. Key points in Singapore's pedestrian system include many aspects from architectural design, economic, to social aspects such as relatively low cost public transport and the high cost of car ownership, almost nonexistence up leveling social status by car ownership, and people's high awareness of healthy living. From urban design perspective, integrated transportation planning includes walking as one of the main transport mediums, the availability of sheltered walkways [7], and most importantly is the ability of pedestrian streets to connect Singapore's various functional areas such as residential, central business district, commercial, and institutional function. Pedestrian streets take the role as the smallest unit of connector between integrated system transportation hubs. Walking also helps improve the neighborhood's economic value, since people are more likely to shop in retail around their walking route. Even in Singapore, the effort of creating a good pedestrian environment is continuing. There is always more need for an integrated system with cycling paths, more promenades, and integrated retails such as alfresco dining[8]. Indoor walking is not an ideal waking environment since it discourages people from getting in touch with streetscape and greenery [9].

Compared to Yogyakarta, the government has started to realize the importance of walking experience in pedestrian oriented design. This can be seen in the Malioboro area where the sidewalk improvement has been going since 2015, but only in 2017 that they started focusing on enhancing people's walking experience by paying more attention to covered walkway, street furniture, and the building frontages [10]. In its long-term development plan, Indonesia has put the enhancement of infrastructure and built environment as two of the top priorities. The enactment of Public Law number 26/2007 about Spatial Planning and Design shows the government's seriousness on the plan. Several official guidelines and ministerial regulations regarding standardization of numerous types of infrastructure have been issued. For example, the Guidelines for Provision and Use of Urban Pedestrian Space Infrastructure and Facilities that is regulated under Ministerial Regulation of Civil Works and Housing number 03-year 2014. The guideline is completed with requirements needed to achieve a fully functional urban 
pedestrian street. However, for some reasons the guideline is hardly implemented in real life urban development.

\section{$3 \quad$ Research Methodology}

Qualitative research was chosen to collect, analyze, and interpret data captured from direct observation on the field. A case study that is further developed by comparative analysis is adopted in this study. Case study is chosen because it enables the author to do site-visit and indepth observation of the subjects of the study. For this study, two cities are chosen to be the observation objects. The first one is Yogyakarta, a major city in Indonesia that, beside the nation's endeavor on creating a greener environment, still struggles in creating a pedestrian friendly environment. The second is the famous city-state of Singapore, which by its garden city concept is one of the most pedestrian friendly cities in Asia (Figure 1).

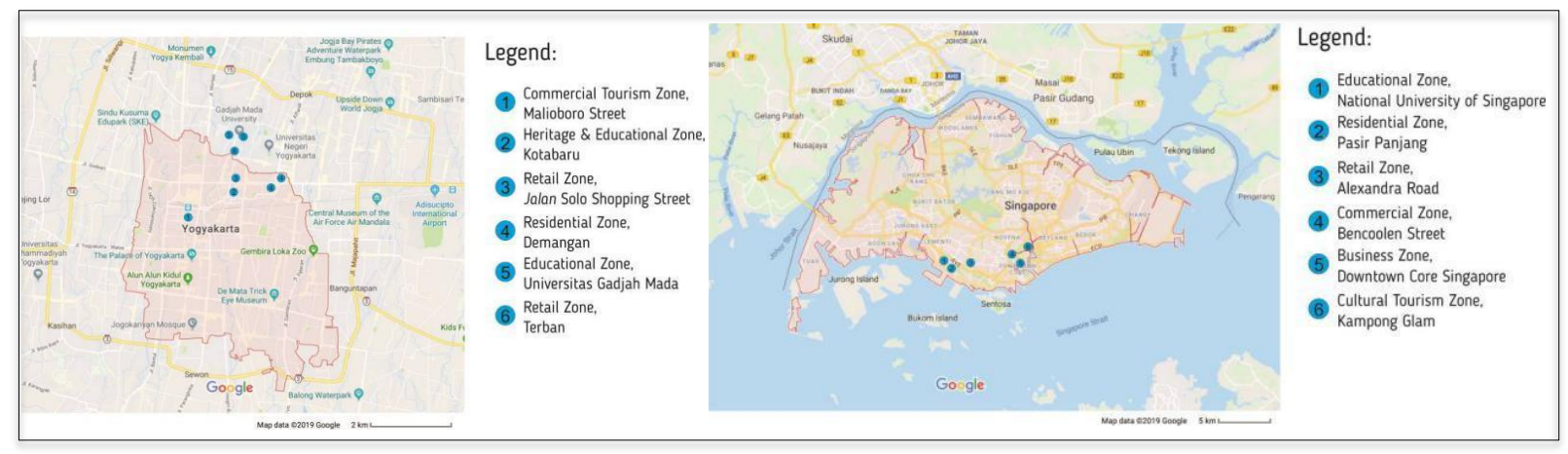

Figure 1 The location of study objects in Yogyakarta and Singapore. Source (Author, 2020)

Samples of several pedestrian streets were selected throughout both cities. The streets represent different urban zoning which include educational zone, residential zone, commercial zone, business zone, and tourism zone. Each zone was personally visited by the author and carefully documented to get information such as the street's physical condition, features, and the designated users. Strategies of acquiring the data includes choosing the location and proximity of the samples within the southern corridor for Singapore and the northern region for Yogyakarta in order to enhance the efficiency of the observation in relevance with time. Collected data from both cities were then compared to formulate general information regarding the designs and issues of both samples. Analysis on pedestrian street facilities was conducted for each city to summarize how well a pedestrian facility is operating from a pedestrian's perspective. This analysis is similar to the level of service analysis that's usually used to analyse transportation facilities [11]. 


\section{$4 \quad$ Results and Discussions}

\subsection{Current Condition of Pedestrian Street in Yogyakarta}

Pedestrian streets in Yogyakarta show different qualities and types. Even streets in one type of land-use zoning can be varying in terms of the physical characteristics. For example, in residential areas, the pedestrian environment can take the form of a small alley between houses to carefully designed sheltered sidewalks. These differences are due to the many types of residential in the city: a landed housing complex built by developer; high rise apartments; and kampong housing, the most common form of residential type in Yogyakarta, in which the houses follow organic patterns and are usually built independently by the house owner. Pedestrian streets give different meaning to the citizens of Yogyakarta throughout the year. In working days around the city center, the pedestrian streets seem to lose their charm since people rely too much on their private vehicles to transport. However, in festive seasons, such as New Year and Eid al-Ftr, the streets become important to the people since it acts like a plaza where a lot of people can gather and enjoy the occasion. Usually on the weekend, some motorized roads like the ones in Malioboro and Kotabaru, are closed to provide an enclosed and larger pedestrian environment for the people to have activity. The event is called Car Free Days (CFD) and takes the role as a short term solution to 'lend' the street to the people. This kind of thing habituates the people to depend overly on the CFD for them to have street-oriented activity. The phenomenon tells us that the people of Yogyakarta are yearning for a good pedestrian environment. Nevertheless, the regulations, land acquisition problem, and the city's organic growth pattern, made the effort of realizing a good pedestrian system in Yogyakarta far from over.

\subsubsection{Malioboro Street}

Since the middle of 2018, Malioboro Street might be the best example of a pedestrian environment in Yogyakarta. Having frontage used as mainly a commercial and heritage center, the east sidewalk along the main street is completely pedestrian friendly. The street is wide in size and has the following features: 1 . Sheltered walkway from the overhang canopy of the buildings; 2. Attractive paving blocks completed with guiding blocks; 3 . various forms of public benches; 4. the availability of bollards; 5 . Street Sculptures that are placed on several spots; 6 . Bicycle dedicated parking space. Those entire features make Malioboro Street life so vibrant especially on the weekend or public holidays. Unfortunately, the street is lacking some greenery or at least the trees are not fully grown yet since the renewal of the street was conducted not too long ago. This shortfall makes the street very hot during the peak of the dry season (Figure 2). 


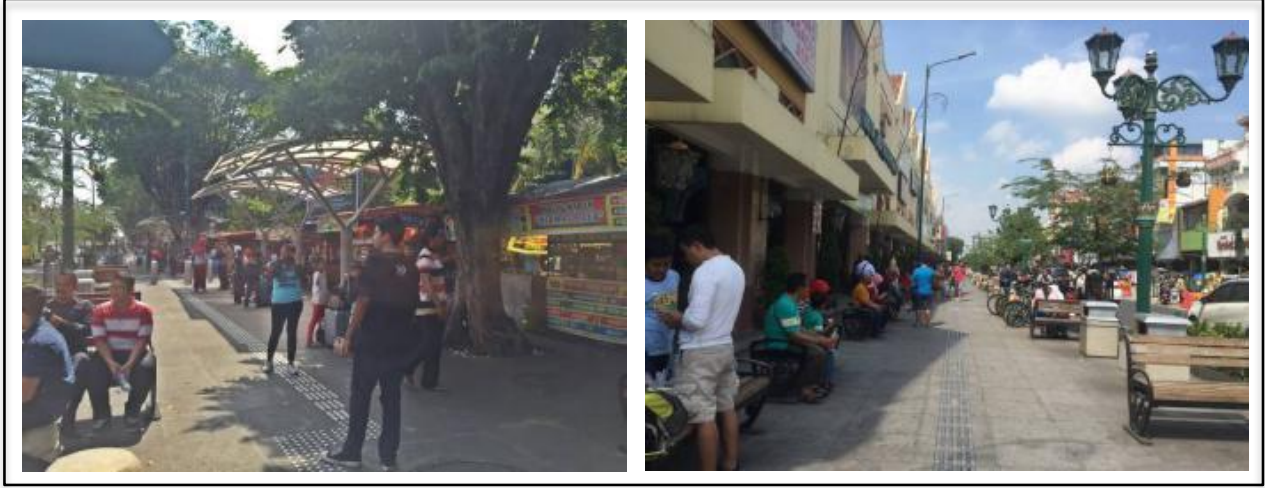

Figure 2 Pedestrian Street at Malioboro. Source (Author, 2020)

\subsubsection{Kotabaru}

Kotabaru is a district located at the north of Malioboro Street. Because of its heritage value that is like Malioboro, this precinct has been undergoing the same treatment as Malioboro Street. Built in the colonial era with a concept of garden city, today's government is trying to restore the garden concept of the area. The pedestrian environment here shows similar features with Malioboro Street but with less ornament such as public sculpture and benches with unique shape. The pedestrian street is not wide but located at both sides of the road and in the middle of the road and acts as a road divider. As seen on Figure 3, the pedestrian oriented design is quite simple but efficient and functional. The provision of bollards adds safety value to the street. However, the seemingly perfect pedestrian street is still not attractive enough for the people to fully occupy the street all day. The heavy traffic around the area and lack of dedicated parking space makes this area not pedestrian friendly in the first place. It will take time and more thought on integrated transport to make this street livelier (Figure 3).

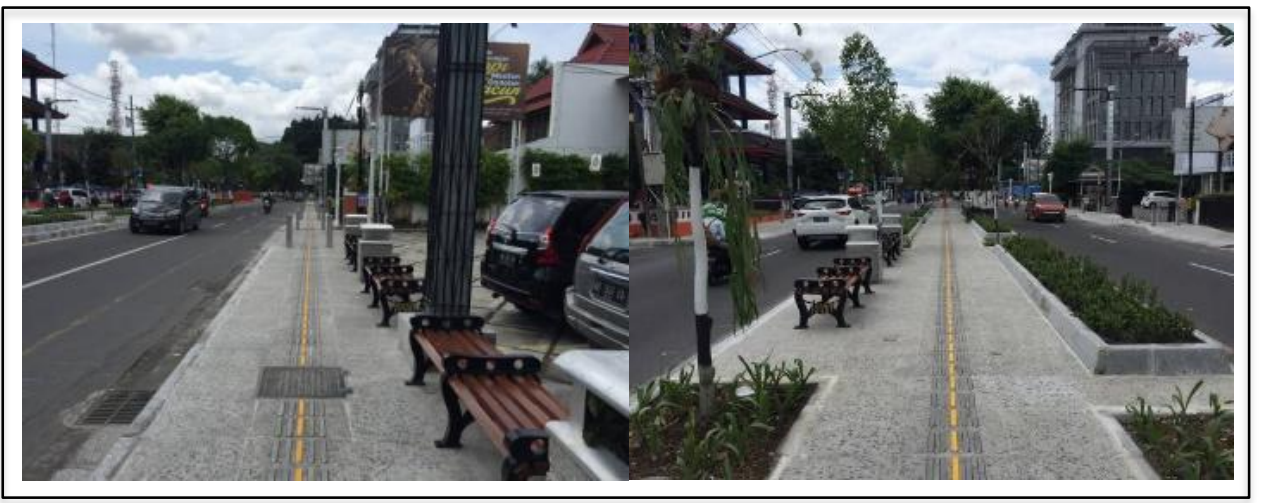

Figure 3 Pedestrian Street at Kotabaru. Source (Author, 2020)

\subsubsection{Jalan Solo}

Jalan Solo is an old shopping street that, if Malioboro is popular for tourists, Jalan Solo attracts more local people. As can be observed in the figures above, the infrastructure of the street is not 
good enough. However, the commercial frontage use along the street attracts people to spend more time walking from one store to another store. The pedestrian street is available on both sides of the road; hence the one-way system of the motorized road is helping in increasing the safety. There is on street parking available along the street, making it convenient for the people to park their car at any section of the street and then walk their way. The street is narrow and only fits for a maximum of two people. The paving block is flat but has no guiding block. Briefly, Jalan Solo shows no characteristic of a good and lively pedestrian environment. However, the street here is livelier than the one on Kotabaru even though Kotabaru offers better infrastructure (Figure 4).

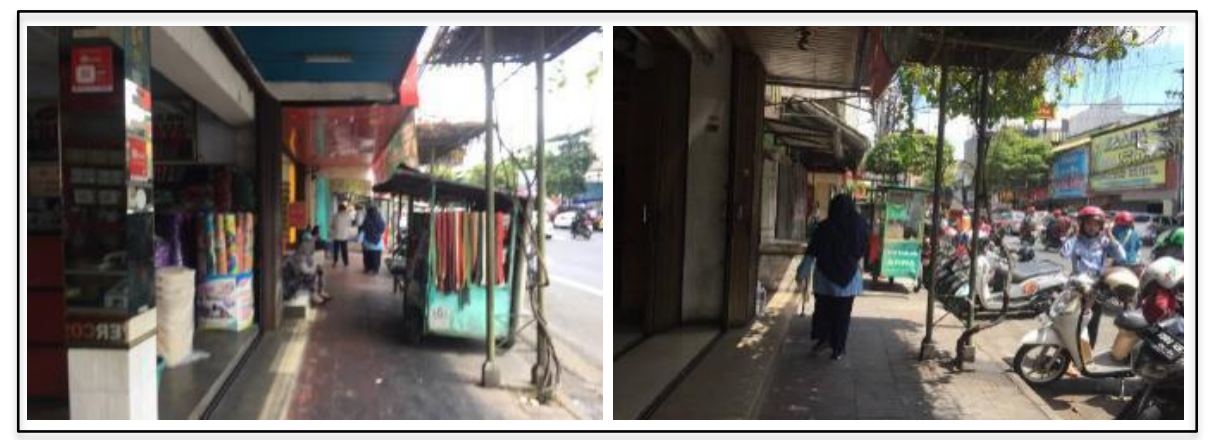

Figure 4 Pedestrian Street at Jalan Solo. Source (Author, 2020)

\subsubsection{Demangan}

The next sample is chosen around the residential area in Demangan Sub district. Even though the residential area is a kampong on type, the physical development of it is like perumahan (residential area developed by private corporation). This uniqueness is probably due to its location which is near one of the major roads in Yogyakarta. The buildings located along the major road usually have double function as residential and commercial spaces. The pedestrian street along the major road shows wide space in front of the buildings and is completed with a planter box that clearly separates the pedestrian street and roads for cars. Because the frontage use along the road is commercial, the pedestrian street is often compromised by motorized vehicles. For example, it is shown on the figure 6 above. There is a car that is crossing the pedestrian street. This incident happens because the car needs to load and unload things for the stores along the road. Even though the streets in front of the buildings are actually public, the store owners tend to consider the street theirs. Sometimes the cars are staying for more than 30 minutes, cutting the pedestrian access. Moreover, this situation creates another major problem which is the misuse of the street as a parking space. Motorcycles would have lined up on the pedestrian street as if the streets belonged to each of the stores (Figure 5). 


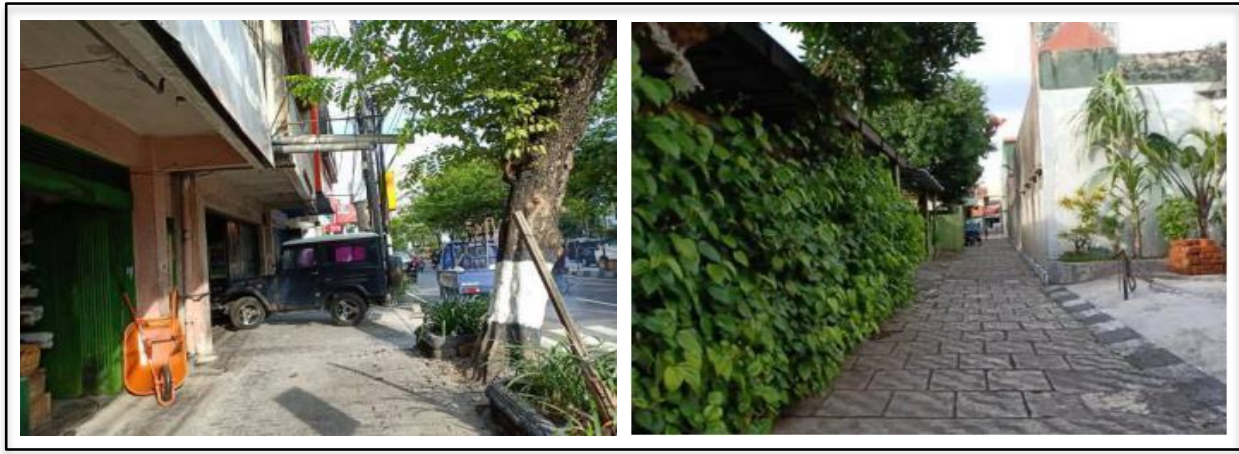

Figure 5 Pedestrian Street at Demangan. Source (Author, 2020)

In the afternoon, several food kiosks are starting to occupy the street. These kiosks are disrupting the pedestrian flow, but it is very hard to eliminate them since people are still buying food from them hence showing that the kiosks are needed. Going deeper into the neighborhood, the streets are getting narrower but there is a clear limitation of vehicles going through the streets, hence it's relatively safer for the people to occupy the streets. The disadvantage of the pedestrian streets here is the different quality of the street side part. Since the streets are attached very closely to each house, the design of the side part follows the design of each house too. For example, one house decides to have walls in front of their house and cover it with greenery, other houses simply have steel fences right next to the street.

\subsubsection{Universitas Gadjah Mada (UGM)}

Being the best university in the city, UGM implemented standardized pedestrian street design throughout the campus. The first observed street is located around the Central Building. The street shows several beneficiary features (Figure 6): 1. Wide, can fit up to five people walking side by side; 2 . covered with paving blocks so that it can still absorb rainwater; 3. Connected with a nearby packing pocket; 4 . Have seating along the street so that people can have some rest between the walks. The street is relatively enjoyable to walk in; however, it only covers the central part of the campus. Besides that, awkward placement of the lamp posts in some places, make the walking experience less attractive. Another place to spot advanced design of pedestrian environments is on the campus park called Wisdom Park. Over there, the street is completely pedestrian only, complete with guiding blocks and seating areas, also surrounded by an abundance of trees as natural shedding. Unfortunately, outside the central part of the campus and the park, the streets are getting worse. For example, the street near the Dentistry faculty, which is very narrow and can only fit for maximum 2 people. The street is not covered by any paving or hardscape so it will be covered with stagnant water when it's raining. On Sekip Street, where several study centres are located, there is no pedestrian facility at all. The streets in front of the buildings consist of open gutters. 


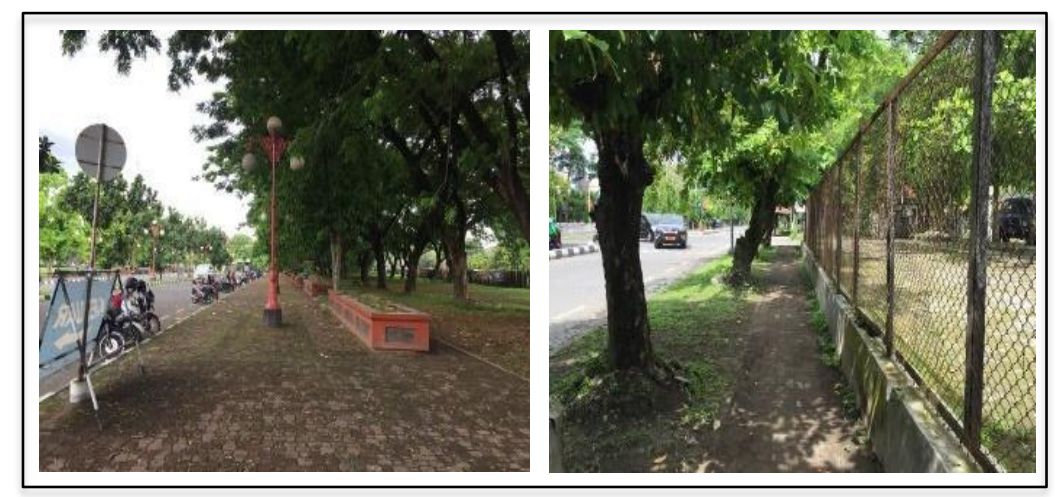

Figure 6 Pedestrian Street at Universitas Gadjah Mada. Source (Author, 2020)

\subsubsection{Terban}

Located near to UGM, Terban is an area mostly consisting of retail along its main street. Like UGM, pedestrian streets here show different conditions (Figure 7). The first one is located at the beginning of the street from UGM. It shows that the street is totally occupied by rows of tailor kiosks, leaving almost no space for people to walk. The existence of these kiosks is somewhat a disturbance yet is needed by the people. This street is now well known as a "tailor center" and a lot of people will go there to fix their clothes. Moving forwards to the Mirota Campus department store which is located after the tailor street. The street here offers more adequate pedestrian facilities even though the size is quite narrow, it offers guiding blocks on its ground. It is also quite convenient since it was located near the department store that has a large parking space. However, the street is disturbed by the awkward placement of planters and electricity boxes that almost occupy the whole street width at some spots (Table 1).

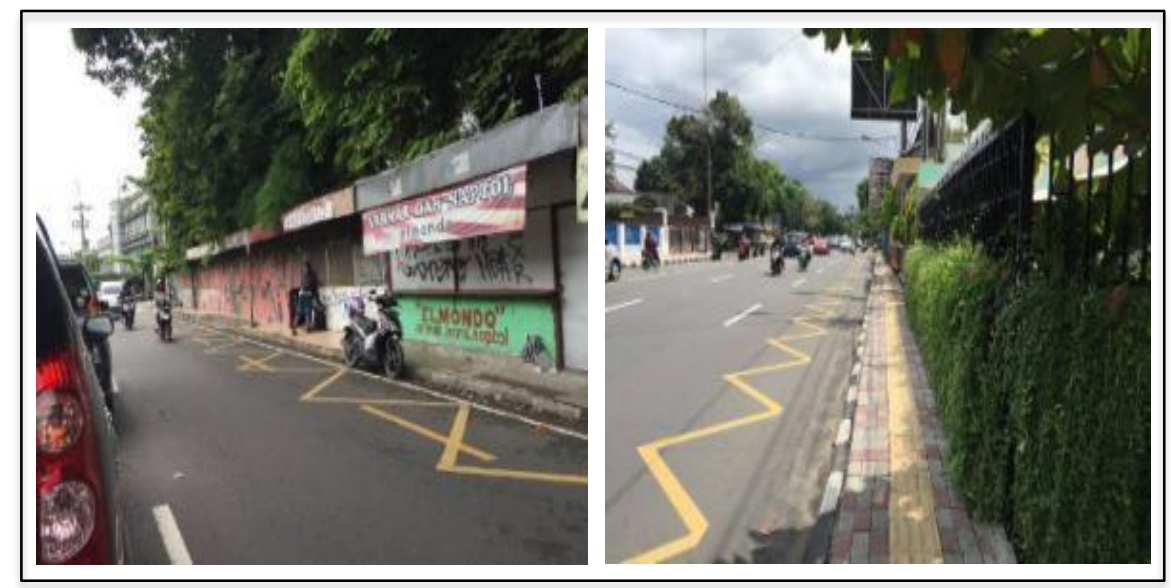

Figure 7 Pedestrian Street at Terban. Source (Author, 2020) 
Table 1 Summary of pedestrian street samples assessment in Yogyakarta

\begin{tabular}{|c|c|c|c|c|c|c|}
\hline Component & $\begin{array}{l}\text { Malioboro } \\
\text { Street }\end{array}$ & Kotabaru & $\begin{array}{l}\text { Jalan } \\
\text { Solo }\end{array}$ & Demangan & $\begin{array}{l}\text { Universitas } \\
\text { Gadjah } \\
\text { Mada }\end{array}$ & Terban \\
\hline $\begin{array}{l}\text { Uses along street } \\
\text { frontage }\end{array}$ & Commercial, retail & $\begin{array}{l}\text { Residential, } \\
\text { education and } \\
\text { heritage } \\
\text { buildings }\end{array}$ & $\begin{array}{l}\text { Commerci } \\
\text { al, retail }\end{array}$ & Residential & Education & $\begin{array}{l}\text { Commercial } \\
\text {, retail }\end{array}$ \\
\hline $\begin{array}{l}\text { Peak of } \\
\text { pedestrian usage }\end{array}$ & Night & Noon & $\begin{array}{l}\text { Afternoon } \\
\text { - Night }\end{array}$ & No peak hour & $\begin{array}{l}\text { Morning and } \\
\text { afternoon }\end{array}$ & $\begin{array}{l}\text { No peak } \\
\text { hour }\end{array}$ \\
\hline $\begin{array}{l}\text { Access to other } \\
\text { transportation } \\
\text { mode (parking } \\
\text { space, bus stop, } \\
\text { etc) }\end{array}$ & $\begin{array}{l}\text { Yes; parking } \\
\text { space, bus stop, } \\
\text { and train station }\end{array}$ & None & $\begin{array}{l}\text { Yes; } \\
\text { parking } \\
\text { space }\end{array}$ & None & $\begin{array}{l}\text { Yes; parking } \\
\text { space and bus } \\
\text { stop }\end{array}$ & $\begin{array}{l}\text { Yes; } \\
\text { parking } \\
\text { space and } \\
\text { bus stop }\end{array}$ \\
\hline $\begin{array}{l}\text { Street events } \\
\text { (public) }\end{array}$ & $\begin{array}{l}\text { Yes } \\
\text { (neighborhood and } \\
\text { cultural event) }\end{array}$ & $\begin{array}{l}\text { Yes (religion } \\
\text { related events) }\end{array}$ & No & $\begin{array}{l}\text { Yes } \\
\text { (neighborhood } \\
\text { events) }\end{array}$ & $\begin{array}{l}\text { Yes (street } \\
\text { market) }\end{array}$ & No \\
\hline \multicolumn{7}{|l|}{$\begin{array}{l}\text { Pedestrian } \\
\text { facilities: }\end{array}$} \\
\hline - Cover/shelter & $\begin{array}{l}\text { Several areas, via } \\
\text { the overstek of the } \\
\text { buildings. }\end{array}$ & No & Yes & No & $\begin{array}{l}\text { Yes, several } \\
\text { area }\end{array}$ & No \\
\hline - Seating & Yes & No & No & No & Yes & No \\
\hline - Greenery & Yes & Very little & Very little & No & Yes & No \\
\hline - Bollard & Yes & No & No & No & No & No \\
\hline $\begin{array}{l}\text { - Public } \\
\text { sculpture }\end{array}$ & Yes & No & No & No & No & No \\
\hline
\end{tabular}

\subsection{Learning from Singapore's Pedestrian Street}

Compared to Yogyakarta, the car ownership rate in Singapore is lower. This can be observed by the number of cars seen on the road. In Singapore, traffic jams happen in a rare hour, usually around 5pm when people go back from work. In Yogyakarta, almost all the time we can see many cars and motorcycles occupy the roads. In peak hours, traffic jams can be very heavy in the city's major roads. In Singapore the crowd is concentrated on the public transport stations such as MRT and bus stops, as well as the street which is the medium for people to walk. This difference makes the role of pedestrian streets in Singapore for its citizens bigger. Especially in highly dense areas, the development of pedestrian environments is more advanced since it is the main transport mode for most people. Walking has been considered the easiest transportation mode and some Singaporeans consider it as either a sport or leisure activity. From direct observation, one of the most important key points in pedestrian system planning in Singapore is that it connects the public transport system. In around 350 meters radius in Singapore, there will be one bus stop. Between the bus stops, people are encouraged to walk to reach the destination 
or another bus stop. However, the quality of each section of pedestrian street is different from one another.

\subsubsection{National University of Singapore (NUS)}

Situated at the Kent Ridge area, the NUS campus has hilly terrain with different ground height scattered around. This topography condition makes it hard to apply universal design on its pedestrian street. For example, on figure 8 where we can see a long stair connecting the lower level of the pedestrian street to the upper level, which is the precinct of The Deck, one of NUS' canteen. Such an arrangement is not wheelchair friendly but also inevitable due to the ridge terrain. Most of the pedestrian streets at NUS are designed like figure 8 shows. It was covered by paving blocks with high water permeability and completed with a green buffer on both sides. Around the campus housing, the pedestrian street shows different designs. The floor is relatively flatter with denser cover. Most of the street is covered with various forms of roofing (seen on picture 8 is glass panel roofing). The reason behind the roofing installation is probably because the street here does not just serve as a walking medium but also as social space for the students who live there. Completed with many cafes, working places, and restaurants, the pedestrian environment in the housing area of NUS offers a wonderful place for social interaction.

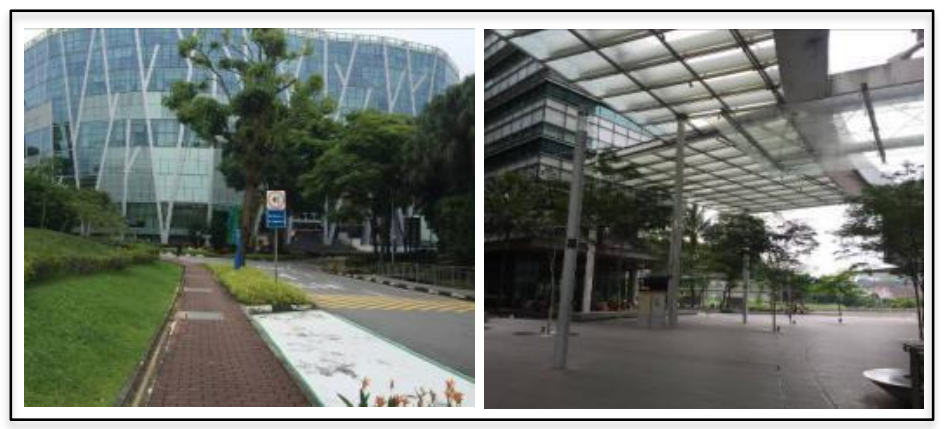

Figure 8 Pedestrian Street at NUS. Source (Author, 2020)

\subsubsection{Pasir Panjang}

South of the NUS' School of Business campus, there exists a residential area that is not common in type compared to other residential areas in Singapore. The area is called Pasir Panjang (lit. Long Sand) and it is due to the location which is on the edge of Singapore's southern coast. The houses here are mostly landed houses with a combination of very low rise (3-4 floors) buildings. Affected by the type of the buildings, the pedestrian streets here are simple and fully serve the function as walking by means of transportation (Figure 9). The pedestrian space is fit for only two people and even though it's considerably far from the road, it is very close to the fence and gate of the houses. The green lawn as a buffer only exists between the street and vehicles road with nothing separating the street from the houses. This might create uneasy feelings since usually in taller residential buildings people have enough space between them and the houses. On the other section of the street, the opposite thing happens. The green 
buffer only exists between the street and the house but none between the street and the road which lessen the safety of the space.

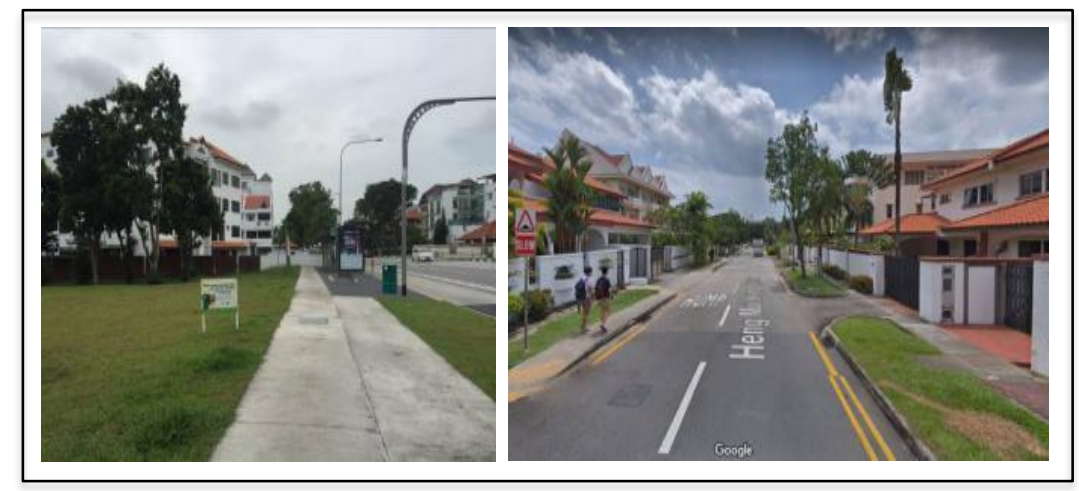

Figure 9 Pedestrian Street at NUS. Source (Author, 2020)

\subsubsection{Alexandra Street}

Alexandra Road is home to some retail places that are famous for local Singaporeans, with Anchorpoint and IKEA to name the few. Located near major two way vehicles roads, the pedestrian street must compete with the traffic (Figre 10). Since the road is considerably wide, almost all crossings in this area are in the form of overhead bridges. The bridges are around 2.5 meters wide and 3.0 meters between the floor and the roof. It provides perfect shelter from vehicles and rain. However, the stairs toward the bridges are quite steep and long making it not accessible for people with walking disability. As for the on the ground pedestrian street, the path is divided into two lanes. The first lane is the one located next to the retail buildings. This path is usually paved with ornamental paving blocks since it also performs as terraces for the buildings. The people who walk in this lane are usually the one who are interested in shopping. The other lane, separated by bushes and trees from the first lane, is located next to the road. The road is narrower and is usually used by people who just want to pass by the street without any intention of stopping.

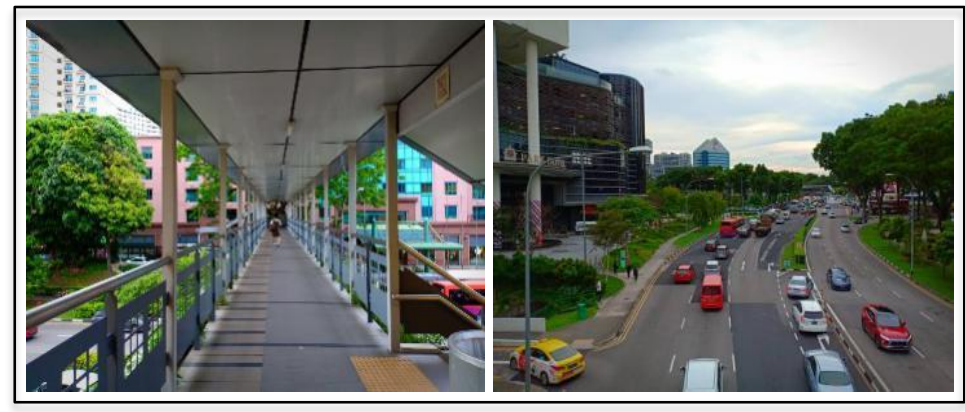

Figure 10 Pedestrian Street at Alexandra Street. Source (Author, 2020) 


\subsubsection{Bencoolen Street}

Located near the downtown area, Bencoolen is home for various types of hotels from the capsule type to the luxurious one. Because of the proximity to the downtown area, the pedestrian street design shows similar quality with the downtown area (Figure 11). The first design attention is about the availability of dedicated bicycle lanes. As seen in the picture, the red path is for bicycles to pass. Unfortunately, there is no physical border between the bicycle path and the pedestrian path. This condition might be harmful in a crowded street situation. Moreover, eventually the cyclists must cross the street and use the same crossing path with the pedestrian. Some part of the pedestrian street is covered by the overhang from nearby buildings. This scheme indirectly provides shelter for the passing pedestrian and creates subtle interaction between the people and the buildings. The street is quite wide, probably because the frontage used is mostly hotels hence many tourists occupy the streets with their luggage. Moreover, there is an on the ground entrance for Bencoolen MRT Station that takes up a wide space on the street.

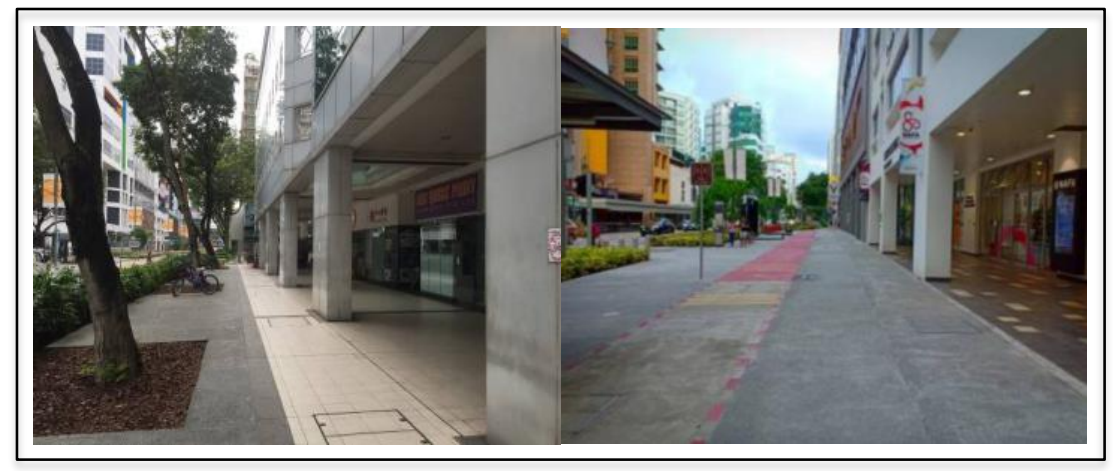

Figure 11 Pedestrian Street at Bencoolen Street. Source (Author, 2020)

\subsubsection{Downtown Core}

Consisting of many high-rise buildings and home to both big corporations and hotels for tourists, downtown core Singapore shows the most advanced pedestrian system in Singapore. The development of the area is centered on Marina Bay, the most famous water body in Singapore. Motorized vehicles are mostly not permitted to go around near the water body, which attracts tourists the most. The most significant pedestrian innovation in this area is the loop system that circles Marina Bay, so that people can go around the bay on foot (Figure 12). The loop goes around for at least $3.50 \mathrm{~km}$ and it takes many forms and is beautifully designed in every section. Three bridges exist as part of the loop and two of them are completely for pedestrians only. Each pedestrian bridge is placed carefully so it also can be a selfie spot with a background of Singapore's landmarks such as The Merlion (Esplanade Bridge), Marina Bay Sands Hotel (Helix Bridge), and Art Science Center (Helix Bridge). The space between the tall buildings can be intimidating for people if it's not designed carefully. In the picture above, we can see that the space is designed to fit human scale by placing greenery as borders. Public benches can be found along the street for people to have a rest. To enhance the walking 
experience, various ground cover techniques are done. In the picture we can see two options of paving on the street. The left one is covered in concrete and the other is covered in more natural material.

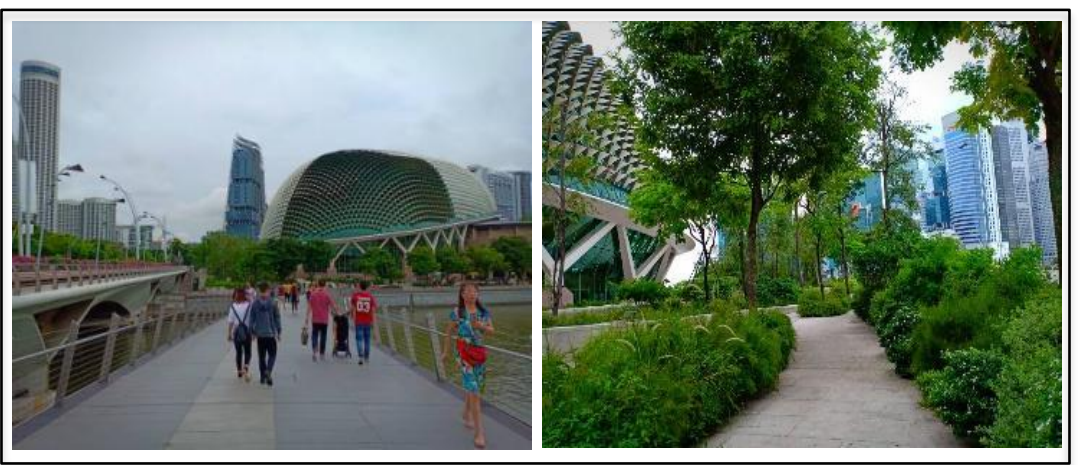

Figure 12 Pedestrian Street at Downtown Core Singapore. Source (Author, 2020)

\subsubsection{Kampong Glam}

Located at the heart of the tourist center and near the downtown core area, Kampong Glam offers unique charm to visitors. Contrast with Marina Bay and its skyscrapers, Kampong Glam is full of rows of traditional shop houses. The maximum height of the shop houses are three stories with the most common height being two stories. Not only the houses, the overall urban fabric of this area has been maintained since the colonial era and hence makes it one of the most visited areas in Singapore by tourists. Beside the shop houses, another striking urban fabric that has not changed is the roads. The roads are narrow and the access for motorized vehicles is limited. The vehicles must pass the roads in low velocity and most of the vehicles will park on the side of the roads. There are several pedestrian-only streets across the area with the most popular one located in front of Sultan Mosque (Figure 13 and Table 2). As we can observe from the picture, the street is covered with oriental pattern paving and forms a good vista with the famous mosque. Flanked by two colorful rows of shop houses on each side, this road offers a nice walking path in the morning till afternoon. At night, most of the restaurants and bars along the street start to open, converting the street into a vibrant hangout place.

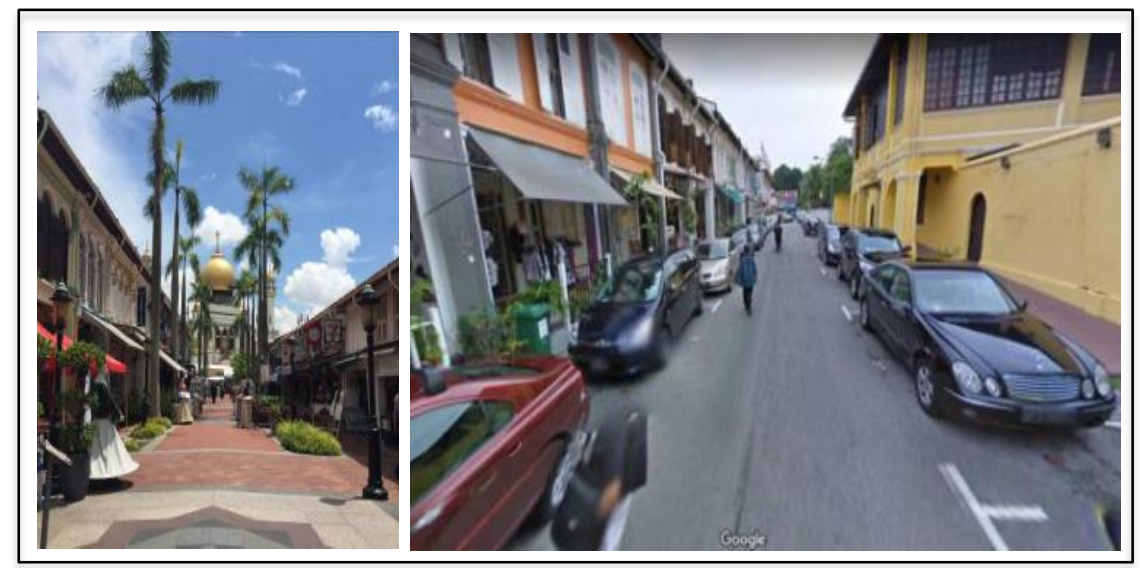

Figure 13 Pedestrian Street at Kampong Glam. Source (Author, 2020) 
Table 2 Summary of pedestrian street samples assessment in Singapore

\begin{tabular}{|c|c|c|c|c|c|c|}
\hline Component & NUS & $\begin{array}{c}\text { Pasir } \\
\text { Panjang }\end{array}$ & $\begin{array}{l}\text { Alexandr } \\
\text { a Street }\end{array}$ & $\begin{array}{c}\text { Bencoolen } \\
\text { Street }\end{array}$ & $\begin{array}{l}\text { Downtown } \\
\text { Core }\end{array}$ & $\begin{array}{c}\text { Kampong } \\
\text { Glam }\end{array}$ \\
\hline $\begin{array}{l}\text { Uses along } \\
\text { street frontage }\end{array}$ & Education & $\begin{array}{c}\text { Residentia } \\
1\end{array}$ & $\begin{array}{l}\text { Comm } \\
\text { ercial, } \\
\text { retail }\end{array}$ & Hotels & $\begin{array}{l}\text { Offices, } \\
\text { hotels, and } \\
\text { public } \\
\text { parks }\end{array}$ & $\begin{array}{l}\text { Hotels } \\
\text { and } \\
\text { heritage } \\
\text { building }\end{array}$ \\
\hline $\begin{array}{l}\text { Peak of } \\
\text { pedestrian } \\
\text { usage }\end{array}$ & Noon & Morning & $\begin{array}{l}\text { Aftern } \\
\text { oon - } \\
\text { Night }\end{array}$ & $\begin{array}{l}\text { Morning } \\
\text { and Night }\end{array}$ & $\begin{array}{l}\text { Afternoon } \\
\text { - Night }\end{array}$ & $\begin{array}{l}\text { Afternoo } \\
\mathrm{n}-\text { Night }\end{array}$ \\
\hline $\begin{array}{l}\text { Access to other } \\
\text { transportation } \\
\text { mode (parking } \\
\text { space, bus } \\
\text { stop, etc) }\end{array}$ & $\begin{array}{c}\text { Yes; } \\
\text { parking } \\
\text { space, bus } \\
\text { stop, and } \\
\text { MRT } \\
\text { station }\end{array}$ & $\begin{array}{l}\text { Yes; bus } \\
\text { stop }\end{array}$ & $\begin{array}{l}\text { Yes, } \\
\text { parkin } \\
\text { g } \\
\text { space } \\
\text { and } \\
\text { bus } \\
\text { stop }\end{array}$ & $\begin{array}{c}\text { Yes; } \\
\text { parking } \\
\text { space, } \\
\text { and MRT } \\
\text { station }\end{array}$ & $\begin{array}{l}\text { Yes, } \\
\text { parking } \\
\text { space, bus } \\
\text { stop, and } \\
\text { MRT } \\
\text { station }\end{array}$ & $\begin{array}{l}\text { Yes; } \\
\text { parking } \\
\text { space } \\
\text { and bus } \\
\text { stop }\end{array}$ \\
\hline $\begin{array}{l}\text { Street events } \\
\text { (public) }\end{array}$ & No & No & $\begin{array}{l}\text { Yes } \\
\text { (Chine } \\
\text { se } \\
\text { New } \\
\text { Year) }\end{array}$ & $\begin{array}{c}\text { Yes } \\
\text { (street } \\
\text { market) }\end{array}$ & $\begin{array}{c}\text { Yes } \\
\text { (tourist } \\
\text { related } \\
\text { events) }\end{array}$ & $\begin{array}{l}\text { Yes } \\
\text { (tourist } \\
\text { and } \\
\text { cultural } \\
\text { related } \\
\text { events) }\end{array}$ \\
\hline \multicolumn{7}{|l|}{$\begin{array}{l}\text { Pedestrian } \\
\text { facilities: }\end{array}$} \\
\hline $\begin{array}{l}\text { - Cover } \\
\text { /shelter }\end{array}$ & $\begin{array}{l}\text { Yes, } \\
\text { several } \\
\text { area }\end{array}$ & No & No & $\begin{array}{l}\text { Several } \\
\text { area, via } \\
\text { the } \\
\text { overstek } \\
\text { of the } \\
\text { building }\end{array}$ & $\begin{array}{c}\text { Several } \\
\text { area, via } \\
\text { the } \\
\text { overstek of } \\
\text { the } \\
\text { buildings }\end{array}$ & No \\
\hline - Seating & No & No & No & Yes & Yes & No \\
\hline - Greenery & Yes & Yes & Yes & Yes & Yes & Yes \\
\hline - Bollard & $\begin{array}{l}\text { Yes, at the } \\
\text { bus stop }\end{array}$ & $\begin{array}{l}\text { Yes, at the } \\
\text { bus stop }\end{array}$ & $\begin{array}{l}\text { Yes, at } \\
\text { the bus } \\
\text { stop }\end{array}$ & $\begin{array}{l}\text { Yes, at } \\
\text { the bus } \\
\text { stop }\end{array}$ & $\begin{array}{l}\text { Yes, at the } \\
\text { bus stop }\end{array}$ & $\begin{array}{l}\text { Yes, at } \\
\text { the bus } \\
\text { stop }\end{array}$ \\
\hline $\begin{array}{l}\text { - Public } \\
\text { sculpture }\end{array}$ & No & No & No & Yes & Yes & No \\
\hline
\end{tabular}

\section{Conclusion}

In relation to the research question, field observation showed that pedestrian streets exist in Yogyakarta but very few people use them. The most visible reason is that pedestrian streets are not exclusively owned by pedestrians. There is no strict practice that forbids vehicles to inhabit the pedestrian streets. The high number of cars itself makes the violation happen more often. We often see sections of pedestrian street used as parking facilities for motorized vehicles or that the border between pedestrian street and vehicle street is often blurred hence making it fairly dangerous for people to walk. The second problem comes from the design aspect, which is mostly confusing and not following the standard. For example, the existence of big planter 
boxes in the middle of the street is totally forbidding people to comfortably cross. The width of the streets is often too narrow for even just two people to walk comfortably and safely. However, several pedestrian streets in Yogyakarta are designed or even growing nicely with many people crossing it daily such as in Malioboro, Kota Baru, and Jalan Solo. However, these streets are not connected spatially with each other, let alone with other pedestrian streets. Observing Singapore as a good precedent for a pedestrian environment, there are two substantial design aspects that can be learned. First is that most pedestrian streets in Singapore are not designed as means of basic transportation only. Some streets are designed to provide leisure activities, some others are meant for tourists, and the rest exist as space for people to get healthier. The second key point is that Singapore's streets are highly connected either between the streets or between the streets and other transportation modes.

The author fully understands that the urban history and planning background for both Yogyakarta and Singapore is different. Starting in the early 1800's when Singapore was still under the British Empire, Sir Thomas Stamford Raffles made a comprehensive plan to control the physical growth of the city, so it followed a specific pattern set by the government [12]. This early plan ensured that the slums were turning into a more orderly environment. Raffles' plan seemed a little bit brutal at that time, but it was indeed the pioneer of the modern and wellorganized Singapore we know today. Being an organic city, Yogyakarta shows different design patterns. Yogyakarta is a much older city than Singapore, in terms of modern governance. Dated since it was an important part of Mataram Kingdom in the 1600's till it was an independent kingdom in the 1800 's, Yogyakarta never had an official urban plan, and hence the physical growth of the city is due to the life force of the city itself. Even though today the city has modern laws concerning urban planning and design, the implementation of such laws is often constrained by tradition and local culture.

This paper shows only a preliminary study of the pedestrian environment in Yogyakarta and to give a depiction on possible enhancement, precedent from neighbouring countries is presented. However, to fully learn how to build a great pedestrian environment from Singapore, it is important to study the history context of the city since the strategies conducted to realize the designs are often related to that. Furthermore, assessment on Yogyakarta's readiness in moving forward toward a car-less and walk-more environment is needed to be done. For future studies, observations on designs of pedestrian environments from other countries and cities need to be conducted to broaden the contextual study.

\section{REFERENCES}

[1] Task Force Group on Environmentally Friendly Vehicles, "Environmentally Friendly Vehicles and the World Forum For the Harmonization of Vehicle Regulations," 2012. 
[3] M. Southworth, "Designing the Walkable City," J. Urban Plan. Dev., vol. 131, no. 4, pp. 246-257, 2005.

[4] R. K. McLellan and J. Borak, Urban Sprawl and Public Health: Designing, Planning and Building Healthy Communities, vol. 47, no. 7. Washington DC, 2005.

[5] Peraturan Menteri Pekerjaan Umum Nomor, Pedoman Perencanaan, Penyediaan, dan Pemanfaatan Prasarana dan Sarana Jaringan Pejalan Kaki di Kawasan Perkotaan, vol. 2013. Indonesia, 2014, p. 8.

[6] Y. Zhang, S. Azzali, P. Janssen, and R. Stouffs, "Design for walkable neighbourhoods in Singapore using Form-based Codes," in IFoU 2018: Reframing Urban Resilience Implementation: Aligning Sustainability and Resilience, 2018, p. 5934.

[7] S. Niu, A. Hu, Z. Shen, S. S. Y. Lau, and X. Gan, "Study on land use characteristics of rail transit TOD sites in new towns-taking Singapore as an example," J. Asian Archit. Build. Eng., vol. 18, no. 1, pp. 19-30, 2019.

[8] C. Hendrawan and Y. Dwisusanto, "KONSEP ACTIVE LIVING DALAM PERANCANGAN JALUR PEDESTRIAN Studi Kasus : Jalan L. L. R. E. Martadinata (Riau), Bandung, Jawa Barat,” J. Tek. Arsit. ARTEKS, 2017.

[9] Y. C. Leow, R. Gakenheimer, and L. Keyes, "Enhancing the Pedestrian Experience in Singapore : A Closer Look at MRT Transfers and CBD Walkability Master of Science," Massachusetts Institute of Technology, 2008.

[10] O. R. Manifesty, "Creating Vibrant Street Life: A Spatial Character Study of Shopping Streets in Yogyakarta," in Emerging Civic Urbanism/Designing for Social Impacts, 2018.

[11] C. E. Kelly, M. R. Tight, M. W. Page, and F. C. Hodgson, "Techniques for Assessing the Walkability of the Pedestrian Environment," 8th Annu. Int. Conf. Walk. Liveable Communities, Walk 21, no. January 2007, p. 13, 2007.

[12] V. Chew, "History of urban planning in Singapore," National Library Board, 2009. [Online]. Available: https://eresources.nlb.gov.sg/infopedia/articles/SIP_1564_2009-0908.html. [Accessed: 03-May-2021] 